\title{
TOKSISITAS AKUT KOMBUCHA DAUN TIN (Ficus carica) DENGAN METODE BRINE SHRIMP LETHALITY TEST (BSLT)
}

\author{
Uswatun Hasanah $^{1)}$, Ernanin Dyah Wijayanti ${ }^{1^{*}}$ \\ ${ }^{1)}$ Akademi Farmasi Putra Indonesia Malang Jl. Barito No. 5 Malang, (0341) 491132 \\ Korespondensi: nanin.wijayanti@gmail.com
}

\begin{abstract}
Fig leaves (Ficus carica) contain secondary metabolites such as flavonoids, tannins, alkaloids, saponins and triterpenoids, which potentially toxic in a certain amount. Fermentation of fig leaves using kombucha produce healthy drink with various bioactivities. The aim of this research was to observe acute toxicity of fig leaves kombucha using Brine Shrimp Lethality Test (BSLT) method. Toxixity test againts Artemia salina Leach larvae using 7 variations in fig leaves kombucha concentration from $100 \mathrm{ppm}$ to $30000 \mathrm{ppm}$. The results showed that fig leaves kombucha LC50 value of 139,99 ppm, so that fig leaves kombucha is potentially toxic.
\end{abstract}

Key words: acute toxicity, BSLT, fermentation, fig leaves

\begin{abstract}
ABSTRAK
Daun tin (Ficus carica) mengandung metabolit sekunder antara lain flavonoid, tanin, alkaloid, saponin dan triterpenoid yang berpotensi toksik dalam jumlah tertentu. Fermentasi daun tin oleh kultur kombucha menghasilkan minuman kesehatan dengan berbagai bioaktivitas. Penelitian ini bertujuan untuk mengetahui toksisitas akut kombucha daun tin menggunakan metode Brine Shrimp Lethality Test (BSLT). Pengujian toksisitas terhadap larva Artemia salina Leach menggunakan 7 variasi konsentrasi kombucha daun tin antara 100 ppm sampai 30000 ppm. Hasil penelitian menunjukkan nilai LC $_{50}$ kombucha daun tin sebesar 139,99 ppm, sehingga disimpulkan bahwa kombucha daun tin berpotensi toksik.
\end{abstract}

Kata kunci: BSLT, daun tin, fermentasi, toksisitas akut 


\section{PENDAHULUAN}

Tanaman tin merupakan salah satu tanaman yang saat ini sudah sangat terkenal dan sering digunakan sebagai alternatif pengobatan oleh masyarakat. Caliskan \& Polat (2011) menyatakan bahwa sekitar $70 \%$ produksi tin di dunia berasal dari negara-negara Mediterania, dimana konsumsi tin dihubungkan dengan manfaat kesehatan dan panjang umur. Joseph and Raj, 2011 dalam Soni et al., (2014) menyatakan bahwa bagian tumbuhan tin yang berbeda seperti buah, biji, daun, batang, tunas dan getah memiliki berbagai manfaat bagi kesehatan.

Diantara tanaman tin, daun merupakan bagian tanaman yang paling banyak dan saat ini telah banyak diolah menjadi bentuk teh kering. Daun tin memiliki kandungan metabolit sekunder lengkap baik itu tanin, saponin, steroid, alkaloid, terpenoid, dan flavonoid. Mawa et al (2013) menyatakan bahwa daun tin mengandung senyawa fenolik, triterpenoid, antosianin dan asam organik. Asam organik dalam daun tin terdiri dari asam oksalat, asam sitrat, asam malat, asam kuinat, asam sikimat dan asam fumarat (Oliveira et al., 2009 dalam Badgujar et al., 2014).

Adanya kandungan senyawa metabolit sekunder dalam daun tin mendukung khasiatnya bagi kesehatan, sehingga banyak digunakan sebagai obat tradisional. Daun tin telah digunakan secara tradisional untuk mengobati batuk, sakit perut, gangguan pencernaan, kehilangan nafsu makan, mencegah anemia dan anthelmintik (Mawa et al., 2013). Ekstrak daun tin juga telah diketahui memiliki aktivitas hepatoprotektif, hipoglikemik dan antipiretik (Patil \& Patil, 2011), antimikroba dan antioksidan (Ahmad et al., 2013).

Penggunaan daun tin dengan cara diseduh atau direbus menghasilkan rasa yang pahit. Oleh karena itu diper- lukan upaya untuk mengurangi rasa pahit, salah satunya melalui proses fermentasi. Fermentasi dapat memperbaiki cita rasa bahan pangan, serta meningkatkan nilai nutrisi dan fungsionalitasnya (Wijayanti \& Setiawan, 2017).

Pada penelitian ini, fermentasi dilakukan menggunakan kultur kombucha yang mengacu pada penelitian sebelumnya dimana kombucha daun tin memiliki aktivitas antihiperurisemia (Az-zahro dkk., 2019) dan antimikroba (Novitasari \& Wijayanti, 2018). Fermentasi kombucha dapat meningkatkan kadar fenolik total pada daun gaharu (Nurmiati \& Wijayanti, 2018). Selain itu, fermentasi juga dapat meningkatkan kadar fenolik total pada jus buah tin (Wijayanti et al., 2017) dan rimpang temu giring (Murelina \& Wijayanti, 2018).

Adanya peningkatan senyawa fenolik pada hasil fermentasi dapat meningkatkan potensi toksik terutama apabila penggunaanya melampaui batas maksimal. Oleh karena itu, pada penelitian ini dilakukan uji toksisitas dengan metode Brine Shrimp Lethality Test (BSLT). Menurut Harwig \& Scot (1971) dalam $\mathrm{Wu}$ (2014), BSLT merupakan metode sederhana untuk uji sitotoksik senyawa bioaktif yang didasarkan pada kemampuan bahan uji dalam membunuh organisme sederhana. BSLT juga merupakan skrining pedahuluan toksisitas ekstrak tanaman, toksin, logam berat, pedstisida dan lainlain (Sarah et al., 2017). Penelitian ini bertujuan untuk mengetahui toksisitas akut kombucha daun tin menggunakan metode Brine Shrimp Lethality Test (BSLT).

\section{METODE PENELITIAN \\ Bahan}

Bahan yang digunakan antara lain kultur kombucha, daun tin varietas green yordania, larva udang (Artemia salina Leach), sukrosa, aquadest, air 
laut, reagent mayer, wagner dan dragendorff, serbuk $\mathrm{Mg}, \mathrm{FeCl}_{3}, \mathrm{NaCl}$, $\mathrm{HCl}$ pekat, Etanol dan $\mathrm{H}_{2} \mathrm{SO}_{4}$.

\section{Fermentasi}

Daun tin dioalah dalam bentuk simplisia. Selanjutnya simplisia daun tin ditimbang sebanyak 7 gram, diseduh dengan air panas sebanyak $1000 \mathrm{~mL}$. Seduhan disaring dan ditambahkan sukrosa sebanyak $10 \% \quad(\mathrm{~b} / \mathrm{v})$ dan dibiarkan dingin. Selanjutnya ditambahkan starter kombucha dan diinkubasi pada suhu $27-28^{\circ} \mathrm{C}$ selama 12 hari (Novitasari \& Wijayanti, 2018).

\section{Identifikasi Fitokimia}

Identifikasi fitokimia dilakukan terhadap senyawa flavonoid, alkaloid, tanin, saponin dan steroid menggunakan metode reaksi warna (Wijayanti \& Susilowati, 2017; Hidayah dkk., 2016 yang dimodifikasi).

\section{Uji Toksisitas Akut}

Telur Artemia salina Leach dimasukkan ke dalam wadah berisi air laut yang dilengkapi dengan penerangan cahaya lampu dan aerator. Telur ditetaskan dalam waktu 24-48 jam sehingga menjadi larva. Selanjutnya sebanyak 30 ekor larva udang Artemia salina Leach dimasukkan ke dalam masing-masing tabung uji yang sudah berisi sampel dengan variasi konsentrasi 100 ppm, 200 ppm, 500 ppm, 1000 ppm, 10000 ppm, 20000 ppm, 30000 ppm masing-masing $2 \mathrm{~mL}$ dan ditambah air laut hingga volume akhir sama, yaitu $4 \mathrm{~mL}$. Kelompok kontrol negatif tidak diberi sampel uji hanya berisi air laut dan larva udang. Pengamatan dilakukan setelah 24 jam dengan menghitung jumlah larva udang yang mati (modifikasi dari Braguini et al., 2018).

\section{HASIL DAN PEMBAHASAN}

Fermentasi seduhan daun tin menggunaka kultur kombucha menghasilkan rasa asam dan manis, bau khas kombucha daun tin dengan warna coklat muda. Proses fermentasi tersebut dapat mengilangkan rasa pahit pada daun tin. Menurut Villareal-Soto et al. (2018) asam utama yang terdapat dalam kombucha antara lain asam asetat, asam glukonat, asam tartarat, asam malat dan sejumlah kecil asam sitrat. Asam-asam tersebut berperan terhadap karakteristik rasa asam yang terbentuk.

Hasil identifikasi fitokimia pada kombucha daun tin menunjukkan hasil positif pada semua senyawa yang diuji, antara lain flavonoid, alkaloid, tanin, saponin dan steroid. Hal ini menunjukkan bahwa adanya proses fermentasi tetap dapat mempertahankan senyawa dalam daun tin, sehingga senyawasenyawa yang berpotensi toksik pun juga masih ada dalam kombucha daun tin. Hasil uji toksisitas kombucha daun tin dapat dilihat pada tabel 1 .

Hasil penelitian menunjukkan bahwa semakin tinggi konsentrasi kombucha daun tin, maka semakin tinggi pula persentase kematian larva dan nilai probitnya. Berdasarkan data tersebut selanjutnya dibuat grafik regresi linier menggunakan Microsoft excel dan diperoleh persamaan regresi linear $y=0,753 x+3,384$ dengan nilai $\mathrm{R}^{2}=0,9581$, yang selanjutnya digunakan untuk menghitung nilai $\mathrm{LC}_{50}$. Pada penelitian ini, nilai $\mathrm{LC}_{50}$ kombucha daun tin yang diperoleh yaitu sebesar 139,9 ppm.

Suatu bahan dikatakan sangat toksik apabila nilai $\mathrm{LC}_{50} \leq 30 \mathrm{ppm}$, toksik apabila $31 \mathrm{ppm} \leq \mathrm{LC}_{50} \leq 1000$ ppm, dan tidak toksik apabila nilai $\mathrm{LC}_{50}$ $>1000$ ppm (Ningdyah dkk., 2015). Berdasarkan hal tersebut, maka kombucha daun tin termasuk dalam kategori toksik.

Toksisitas kombucha daun tin terhadap larva udang berhubungan dengan kandungan senyawanya. Seperti yang telah disebutkan pada hasil identifikasi fitokimia, kombucha daun tin positif mengandung flavonoid, 
alkaloid, tanin, saponin dan steroid. Menurut Rita et al. (2008) dalam Putri dkk. (2012), senyawa-senyawa tersebut memiliki mekanisme kerja dengan bertindak sebagai stomach poisoning atau racun perut, sehingga apabila senyawasenyawa ini masuk ke dalam tubuh larva, maka alat pencernaannya akan terganggu. Senyawa ini dapat menghambat reseptor perasa pada daerah mulut larva sehingga larva gagal mendapatkan stimulus rasa dan tidak mampu mengenali makanannya yang mengakibatkan larva mati kelaparan.

\section{KESIMPULAN}

Berdasarkan hasil penelitian ini dapat disimpulkan bahwa kombucha daun tin dapat menyebabkan kematian pada $50 \%$ hewan uji pada konsentrasi 139,9 ppm. Nilai LC 50 tersebut menunjukkan bahwa kombucha daun tin termasuk dalam kategori toksik pada rentang 30 ppm sampai 1000 ppm

\section{UCAPAN TERIMAKASIH}

Pada kesempatan ini, peneliti ingin mengucapkan terima kasih kepada Dirjen Belmawa Ristekdikti yang telah menyediakan dana penelitian melalui Program Kreativitas Mahasiswa (PKM) tahun anggaran 2019.

\section{DAFTAR PUSTAKA}

Ahmad, J., Khan, I., Khan, S \& Iqbal, D., 2013, 'Evaluation of Antioxidant and Antimicrobial Activity of Ficus carica Leaves: an In Vitro Approach', J Plant Pathol Microb 4 (1), 1-4.

Az-zahro, S.A.J., Umami, S.H., Hasanah, U., Wijayanti, E.D., 2019, 'Aktivitas Antihiperurisemia Teh Asam Daun Tin (Ficus carica) terhadap Tikus Putih (Rattus norvegicus)', Kartika: Jurnal Ilmiah Farmasi 7 (1), 22-26.

Badgujar, S.B., Patel, V.V., Bandivdekar, A.H., Mahajan, R.T.,
2014, 'Traditional Uses, Phytochemistry and Pharmacology of Ficus carica: A Review', Pharmaceutical Biology 52 (11), 14871503.

Braguini, W.L., Pires, N.V., Alves, B.B., 2018, 'Phytochemical Analysis, Antioxidant Properties and Brine Shrimp Lethality of Unripe Fruits of Solanum viarum', J Young Pharm 10(2), 159-163.

Caliskan, O. \& Polat, A.A., 2011, 'Phytochemical and Antioxidant Properties of Selected Fig (Ficus carica L.) Accessions From The Eastern Mediterranean Region of Turkey', Scientia Horticulturae 128: 473-478.

Hidayah, W.W., Kusrini, D. \& Fachriyah, E., 2016, 'Isolasi, Identifikasi Senyawa Steroid dari Daun Getih-Getihan (Rivina humilis L.) dan Uji Aktivitas sebagai Antibakteri', Jurnal Kimia Sains dan Aplikasi 19 (1), 32-37.

Mawa, S., Husain, K., \& Jantan, I., 2013, 'Ficus carica L. (Moraceae): Phytochemistry, Traditional Uses and Biological Activities', Hindawi Publishing Cor: Evidence-Based Complementary and Alternative Medicine, Vol 2013, Article ID 974256, 1-8.

Murelina, E.M. \& Wijayanti, E.D., 2018, 'Perbandingan Kadar Fenolik Total Sari Rimpang Temu Giring (Curcuma heyneana) Segar dan Terfermentasi', Journal CisTrans (JC-T) 2 (2), 20-24.

Ningdyah, A.W., Alimuddin, A.H. \& Jayuska, A., 2015, 'Uji Toksisitas Dengan Metode BSLT (Brine Shrimp Lethality Test) Terhadap Hasil Fraksinasi Ekstrak Kulit Buah Tampoi (Baccaurea macrocarpa)', JKK 4(1), 75-83.

Novitasari, E.D. \& Wijayanti, E.D., 2018, 'Aktivitas Antimikroba Teh Asam Daun Tin (Ficus carica) 
Secara In Vitro', Journal CisTrans (JC-T) 2 (2), 25-29.

Nurmiati \& Wijayanti, E.D., 2018, 'Perbandingan Kadar Fenolik Total Antara Seduhan Daun Gaharu Dan Kombucha Daun Gaharu (Aquailaria malaccensis)', Journal Cis-Trans (JC-T) 2 (1), 6-11.

Patil, V.V. \& Patil, V.R., 2011, 'Ficus carica Linn: An Overview', Research Journal of Medicinal Plant 5 (3), 246-253.

Putri, M.K.D., Pringgenies, D. \& Radjasa, O.K., 2012, 'Uji Fitokimia Dan Toksisitas Ekstrak Kasar Gastropoda (Telescopium telescopium) Terhadap Larva Artemia salina', Journal Of Marine Research 1 (2), 58-66.

Sarah, Q.S., Anny, F.C. \& Misbahuddin, M., 2017, 'Brine Shrimp Lethality Assay', Bangladesh J Pharmacol. 12, 186-189.

Soni, N., S. Mehta, G. Satpathy, R. K Gupta. 2014. Estimation of Nutritional, Phytochemical, Antioxidant And Antibacterial Activity of Dried Fig (Ficus carica). Journal of Pharmacognosy and Phytochemistry; 3 (2): 158-165.
Villareal-Soto, S.A., Beaufort, S., Bouajila, J., Souchard, J., Taillandier, P., 2018, 'Understanding Kombucha Tea Fermentation: A Review', Journal of Food Science 83 (3), 580-588.

Wijayanti, E.D. \& Setiawan, N.C.E., 2017, 'The Effect of Lactic Acid Fermentation on Fig (Ficus carica) Fruit Flavonoid', Journal of Biological Researches 23 (1), 39-44.

Wijayanti, E.D., Setiawan, N.C.E. \& Cristi, J.P., 2017, 'Effect of Lactic Acid Fermentation on Total Phenolic Content and Antioxidant Activity of Fig Fruit Juice (Ficus carica)', Advances in Health Sciences Research (AHSR)2, Atlantis Press, Proceeding of 1st Health Science International Conference, Malang, Indonesia, October 4-5, 2017, pp. 282-289.

Wu, C., 2014, 'An Important Player in Brine Shrimp Lethality Bioassay: The Solvent', J Adv Pharm Technol Res. 5 (1), 57-58.

\section{LAMPIRAN}

Tabel 1. Analisis Probit Kematian Larva

\begin{tabular}{cccccc}
\hline $\begin{array}{c}\text { Konsentrasi } \\
(\mathrm{ppm})\end{array}$ & Log ppm & $\begin{array}{c}\text { Total He- } \\
\text { wan Uji }\end{array}$ & $\begin{array}{c}\text { Total Larva } \\
\text { Mati }\end{array}$ & $\begin{array}{c}\text { \% Ke- } \\
\text { matian }\end{array}$ & Probit \\
\hline 100 & 2 & 30 & 11 & $37 \%$ & 4.47 \\
200 & 2.3010 & 30 & 17 & $57 \%$ & 5.18 \\
500 & 2.6989 & 30 & 22 & $73 \%$ & 5.61 \\
1000 & 3 & 30 & 23 & $77 \%$ & 5.74 \\
10000 & 4 & 30 & 27 & $90 \%$ & 6.28 \\
20000 & 4.3010 & 30 & 28 & $93 \%$ & 6.48 \\
30000 & 4.477121 & 30 & 29 & $97 \%$ & 6.88 \\
\hline
\end{tabular}

